\title{
European virtual classrooms: building effective "virtual" educational experiences
}

\author{
Nicoletta Di Blas · Caterina Poggi
}

Received: 1 February 2006/ Accepted: 13 November 2006

(C) Springer-Verlag London Limited 2007

\begin{abstract}
This paper presents Learning@Europe, an educational service, supported by VR, that has involved in year 2004-2005 more than 1,000 students from 6 different European countries. L@E has fostered the creation/reinforcement of three different kinds of communities: (1) the classroom community (reinforcing the bonds among students, and between students and their teachers), (2) communities among different schools competing together through 3D environments, (3) a global community (roughly involving $20 \%$ of the total) of all the teachers and students. A similar situation was created, at regional level, in the Italian Region of Lombardy, involving nearly 800 individuals. Given that the behaviours of the different communities in the two projects were very similar, it seems to be arguable that a pattern of community building through virtual environments has been detected. The important facts (detected by surveys of teachers and students, inspection, direct observation, qualitative data analysis) about these communities are: (1) the depth of the pedagogical impact, in terms of increased knowledge (about history and related subjects), skills (use of functional English, use of ICT in learning/teaching processes, group work) and attitudes (more curiosity towards history, increased motivation in school activities, improved respect and interest for other cultures). (2) The engagement of all the participants, with very
\end{abstract}

\footnotetext{
N. Di Blas $(\varangle) \cdot$ C. Poggi

Electronics and Information, Politecnico di Milano,

Via Ponzio 34/5, 20133 Milan, Italy

e-mail: diblas@elet.polimi.it

URL: http://hoc.elet.polimi.it/

C. Poggi

e-mail: poggi@elet.polimi.it
}

high level of customer satisfaction. (3) The depth of the social impact, reinforcing existing relationships (within the same class) and creating new ones. The key feature of this success apparently lies in the sense of "social virtual presence", that is, a feeling of being engaged in a virtual situation, so strong that the technological means become "transparent" and the social situation (meant at different levels and for different time frames) becomes "the king". The paper will present the project, its main features and its outcomes, eventually discussing the role of social virtual presence into building effective and lively communities.

Keywords Virtual presence - Social presence . e-Learning $\cdot$ Virtual community $\cdot$ Educational experience

\section{Introduction}

Can virtual reality technologies give a contribution to the e-Society, by providing the means for creating substantial virtual communities?

This paper presents Learning@Europe (L@E), a project developed by Politecnico di Milano in collaboration with Accenture International Foundation, and Stori@Lombardia (S@L), a similar project funded by the Regional Government of Lombardy (Italy), both involving online learning communities based on a shared 3D virtual environment. We argue that virtual reality can highly enhance virtual communities by producing a strong effect of social presence, i.e., the impression of being together with other participants. Data collected through a large-scale implementation of L@E and S@L, involving over 1,800 students and 
teachers from all over Europe, show the remarkable impact of this experience in terms of engagement, social and educational benefits.

The paper first presents some background literature about online communities and social presence, then proceeds to describe the two projects and the main results of their evaluation. In the end some conclusions are drawn, regarding the role of virtual reality in supporting and enhancing virtual communities.

\subsection{What is a community?}

Communities, both virtual and real, are formed so that a set of people sharing certain purposes, policies, and resources-including the infrastructure that allows them to meet-may support each other in the achievement of their goals (Preece 2000).

With the advent of Internet technologies, communities are less and less determined by spatial boundaries. Internet allows people with common interests and goals to meet regardless of their geographical location, and other barriers such as age, social status, ethnical group, etc., become easier to overcome. Interlocutors cannot rely, as in face-to-face communications, on visual and auditory cues such as physical appearance, facial expressions, gesturing, intonation, etc. (Walther 1992). This can be a great advantage and a great disadvantage at the same time. On one hand, people who are shy in face-to-face conversations can find in the forum a powerful means for expressing themselves. Studies indicate that the absence or reduction of social context cues in computer-mediated communication tend to limit the effect of role status, give greater freedom from social structures, and increase equality (Sproull and Kiesler 1986; Postmes et al. 2002). On the other hand, people are much more easily misunderstood than in face-to-face conversation: understanding correctly the tone of a message, or the references to elements outside the text, can become very difficult.

\subsection{Proxemic semiotics}

Interlocutors who are together in a virtual environment can take advantage of the phenomena studied by proxemic semiotics (Hall 1966), i.e., all the signs conveyed by an agent by means of his or her actions and position. For example, a person may be able to know what the others are doing with no need to ask, just by seeing their avatars (i.e., their virtual counterparts), moving in the virtual world. This partial sharing of context speeds up communication significantly, and reduces the probability of misunderstanding.
1.3 Virtual presence

However, the real advantage of a 3D environment over virtual communities based on "2D" technology is its capacity to create virtual presence, i.e., the subjective feeling of "being there" (Sheridan 1992; Held and Durlach 1992; Heeter 1992; Lombard and Ditton 1997; Witmer and Singer 1998; Carassa et al. 2004), in a place different from one's physical location. If participants, after experiencing a virtual environment, remember it as having visited a "place" rather than as having seen images generated by a computer (Slater 1999), then the environment was successful in creating virtual presence. Presence is "the defining experience" for virtual reality (Mikropoulos and Strouboulis 2004).

Why is virtual presence desirable? The impression of "being there" with people who in fact are not sharing one's physical location makes interaction and remote collaboration smoother, more natural and engaging. The virtual community feels more real, the impression of being together with the other members is stronger. Moreover, presence is thought to intensify, increase, or enhance enjoyment, involvement, task performance and training, persuasion, memory (Lombard and Ditton 1997); "designers share the assumption that increases in self-presence are correlated with higher levels of cognitive performance, and, possibly, emotional development" (Biocca 1997). This is certainly desirable in a community with educational purposes.

There are several factors believed by researchers to increase presence; one of them is control (Witmer and Singer 1998). The more users feel in control of their avatars' movements in the 3D world, the less they are aware of the technology they are using: if they immediately see the system responses to their actions, if the system offers multiple possibilities of viewing or manipulating objects, the users' sense of presence increases. Heeter (1992) calls this perception personal presence, and, to the extent to which the $3 \mathrm{D}$ world changes in response to users' manipulation, environmental presence.

Another important factor in increasing the degree of presence is realism, i.e., the consistency of a virtual environment with the experience of users in the real world (Witmer and Singer 1998; Schubert et al. 1999). High-quality virtual reproduction of real places, such as the Valley of the Kings in Egypt, Monticello plantation, ancient Olympia (Johnson 2005a; Kenderdine 2001), seek to convey an idea as faithful as possible of the real world experience. However, 3D technology can hardly convey the "magic" of being in the real 
place, and photographs, drawings, movies or other media generally produce better results in terms of image quality.

Realism, as intended by virtual presence experts, means that the stimuli experienced are consistent and continuous, at least as far as texture, resolution, lighting, dimensions, and field of view are concerned. Any abrupt interruption in this flow of sensory data is likely to break the impression of presence. A "break in presence" occurs when the participant stops responding to the stream of sensory data coming from the virtual world and instead responds to the sensory stream of the real world in which the experience is taking place (Slater and Steed 2000; Brogni et al. 2003).

Yet, realism depends also on the degree to which a situation is meaningful to the users. This is why struggling to reproduce the real world as faithfully as possible is neither necessary nor sufficient. There is no sense of presence without involvement, and involvement depends on the degree to which stimuli, activities, or events are significant to the user. In fact, involvement is defined as "a psychological state experienced as a consequence of focusing one's energy and attention on a coherent set of stimuli or meaningfully related activities and events" (Witmer and Singer 1998). This is why a careful planning of the activities to be performed in the shared 3D world is even more important than the features of the 3D world itself: what makes the virtual experience really meaningful to the users-and therefore involving-is not the virtual environment in itself, it's what they do in it.

While interaction with the 3D world must certainly be interesting, it should not divert a user's attention from the other users: after all, social interaction is the main purpose of a shared virtual environment, and one of the most effective ways of conveying the sense of "being there" is social presence, derived from the fact that other users acknowledge your existence in the 3D world (Heeter 1992).

However, letting the users into the virtual world and expecting that engaging, exciting interactions will take place spontaneously, is not realistic. Experience with Virtual Leonardo, a previous project of Politecnico di Milano (see the works of Barbieri 2000; Barbieri and Paolini 2000, 2001; Barbieri et al. 1999, 2001; Bucciero et al. 2005) taught that users hardly engage in meaningful interaction with each other or with the virtual environment-and ultimately do not feel compelled-if they are not given a good reason to do so. A $3 \mathrm{D}$ experience must therefore be carefully designed in order to engage participants in meaningful interactions, able to produce social presence.

\section{Learning@Europe: experiencing a european virtual community}

This section describes Learning@Europe, an educational service developed by the HOC laboratory of Politecnico di Milano. L@E is a very complex experience mingling different "ingredients": interaction in a shared 3D world, discussion in a $2 \mathrm{D}$ chat panel, interaction via electronic forums, various classroom activities, studying and researching, etc. L@E (like Stori@Lombardia, an analogous service) is an evolution of the first 3D world-based educational experience designed by Politecnico di Milano: SEE, Shrine Educational Experience (see the works of Di Blas et al. 2003a, b, 2004, 2005a, b, c, d, e, 2006). This section describes a Learning@Europe experience as it was structured during the first project's implementation in Spring 2005, which involved about 1,000 high-school students and teachers from 6 European countries: Italy, France, Spain, Norway, Belgium, and Poland. Minor changes in the sequence of educational activities have been introduced in the second implementation, started in November 2005, and involving 10 additional countries: Bulgaria, Hungary, Germany, Greece, United Kingdom, Czech Republic, Romania, Latvia, Estonia, and Lithuania. Given that participants come from many different countries, the language of all interactions, project documents, and study materials, is English.

The learning experience of Storia@Lombardia is analogous to the one of Learning@Europe, with the exception of the language (Italian), the nationality of participants (all from the Region of Lombardy, but from different towns) and the historical period tackled (city-states in the Middle Ages, rather than nationstates in Modern History), and will therefore not be described.

\subsection{Structure of a Learning@Europe experience}

Each L@E experience lasts between 6 weeks and 2 months, and involves four classes of students from four different high schools and possibly four different countries. Classes are paired to form two teams, which will take part in a cultural competition continuing through the whole experience. Teams are always formed by students of two different countries, who have to collaborate synchronously and asynchronously in order to win the competition (Fig. 1).

Synchronous activities take place in a multi-user virtual world accessible over the Internet, where the four classes meet for four cooperative sessions lasting about $1 \mathrm{~h}$ each. Two students per class control an 
"avatar" (i.e., graphical human-shaped representation of a user, see Figs. 2, 3, 4) in the 3D world, and communicate via chat with the other participants and the online tutors: members of L@E staff who coordinate and lead the sessions. During synchronous online meetings students engage in social activities, such as discussions about the subject matter (i.e., the history of European nation-states), presentation of students' artefacts, and games. Students are required to study detailed history-related contents before every session, and their score in the competition depends on how well they answer the tutors' quizzes and solve the cultural riddles embedded in the games. Moreover, a third computer enables an additional student per class to take part in a separated chat (the "2D chat", not accompanied by a 3D world) and answer the tutor's difficult conceptual questions, thus contributing to the team's score. This is why every student at the keyboard needs a group of classmates circling around and helping to formulate the answers.

In the intervals between sessions, students read contents in the format of interviews to European experts of history, sociology and politics, and prepare works to show in the $3 \mathrm{D}$ world in collaboration with their remote team partners, exchanging ideas and materials on a forum. They also have the opportunity to interact on the Public Forums with all other students (and teachers) currently participating in L@E, and even post questions to the experts. Thus a virtual community of European students can take form to discuss issues that are interesting to all, and benefit from the involvement of experts at academic level.

\subsection{Sequence of activities in-the-large}

Activities in the 3D world are designed to make the most of interaction among students of different countries, both in terms of engagement through social presence, and in terms of educational value.

In Session 1 students meet for the first time the other participants and the online tutors. They introduce each other in turn, showing images of their class, town and country (Fig. 2), and a brief HTML presentation that they were asked to send in advance. They also get a general introduction to the project and the 3D world.

By Session 2 they have read the first set of interviews (about the history of the countries involved), have chosen a symbol for their team collaborating with their remote partners on the team forum, and are ready to begin the cultural competition! Online tutors start a cultural discussion by showing images, quotes and quizzes related to the materials, and students answer via chat. Visual and textual content is shown through pop-up windows that the tutor activates from hotspots (called "boards") in the 3D world (Figs. 3, 4). A Treasure Hunt game follows, where teams have to find in a labyrinth the four objects (out of 12) that are related to a clue assigned by the tutor. Each object needs to be clicked by two team members in order to be selected: thus players are forced to collaborate, using a special "team-whisper" chat that allows them to communicate without being "heard" by the other team.

The structure of Session 3 is basically the same: after a cultural discussion based on the second set of materials, students play a Quiz game, where the fastest player at performing a physical ability game (such as flying through a series of circles, see Fig. 10) earns the right to answer the quiz-question first.

Finally, Session 4 is entirely dedicated to the student's presentation and discussion of their research works.

By the last meeting, in fact, students need to elaborate a research assignment based on the topics they have studied, requiring them to investigate through the
Fig. 1 Structure of L@E synchronous and asynchronous collaborative activities

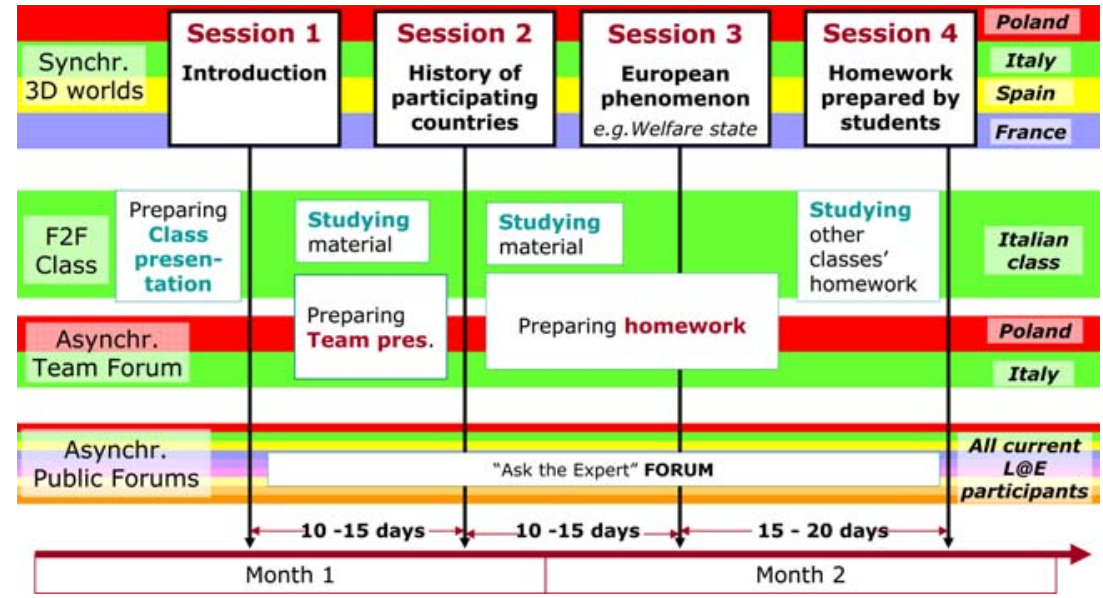




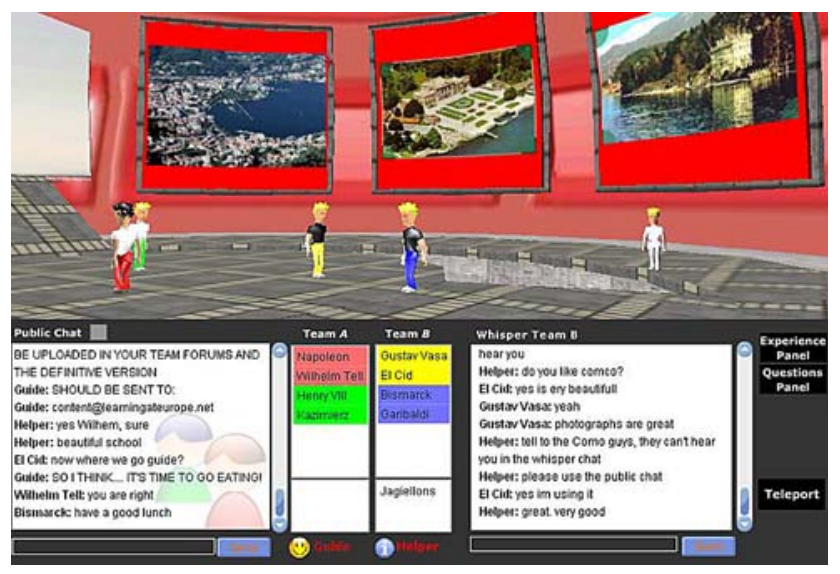

Fig. 2 Avatars present their town in Session 1

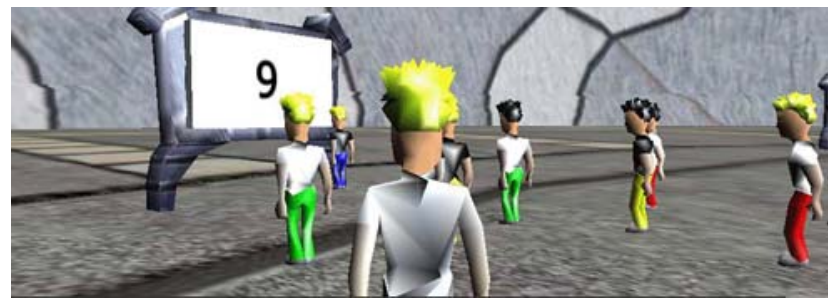

Fig. 3 Avatars during a cultural discussion

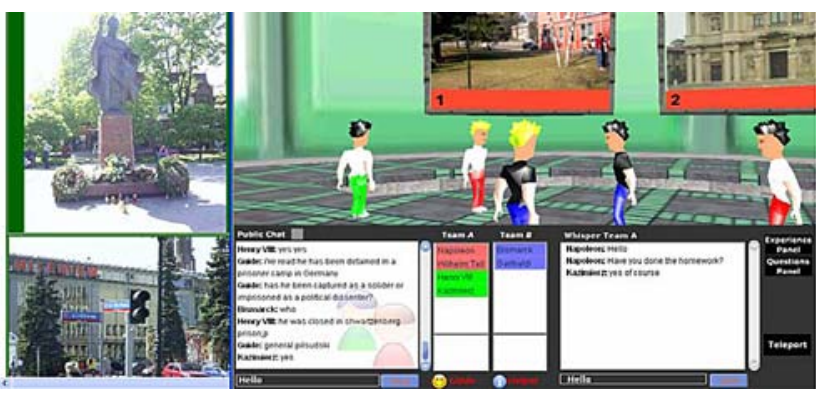

Fig. 4 Pop-up content activated from boards

material evidences of their local history and to compare their own country with the team partners', discussing analogies and differences. The main purpose of having students from different parts of Europe meet in a virtual location and interact with each other, is to create a virtual community (a sort of European virtual classroom) where sharing everyone's national history helps all to develop a more aware, more complete picture of their own local and European identity.

\subsection{In-the-small sequence: what happens during a session}

While teachers and online tutors perform a fundamental supervising role, the real protagonists of a cooperative session are the students: not only those with their hands on mouse and keyboard, but also the groups of "supporters" around them (Fig. 5).

At a given moment, a student in a class is either controlling an avatar in the 3D world, or writing in the parallel " $2 \mathrm{D}$ " chat, or supporting those at the computers by suggesting answers to questions, helping with translation to and from English, pointing at relevant objects in the 3D environment, or cheering. Teachers' feedback in surveys and focus groups, as well as our experience of on-field direct observation in schools, show that these roles are very interchangeable and that students take turns not only between a session and the following, but also during the session.

The fact that only three computers for the entire class are available to take part in synchronous sessions entails that every movement or message of an avatar in the 3D environment is intended not as an individual's decision, but as a joint action of a group. In fact, students controlling one avatar often refer to themselves as "we" rather than "I", e.g.: "El Cid: we are two girls and one man", "Kazimierz: we are polish boys".

Tables 1,2, and 3 synthesize the different ways students interact with the 3D environment, the chat, and their physical surroundings, in different sessions. In each phase, a number of students perform together the different actions (Figs. 6, 7, 8, 9, 10, 11).

Tables 1, 2, and 3 show how collaborative every activity is: even though only one user actually moves the avatar, decisions about where to go and what to do are taken by a group. A few features are inherently collaborative: the Team Whisper Chat, used for exchanging messages that the opposing team must not receive; the Treasure Hunt objects that are not selected until at least two team partners jointly select them.

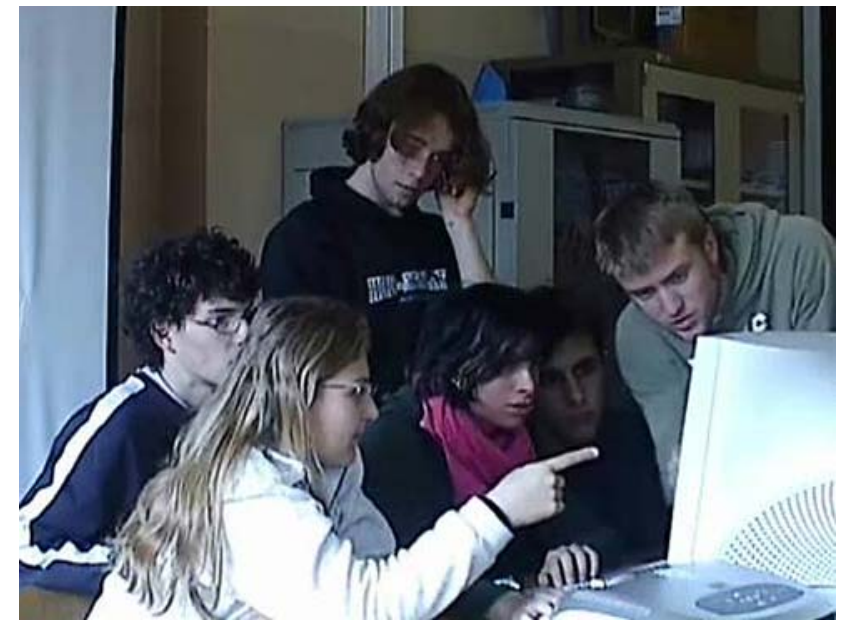

Fig. 5 Players and "supporters" around one computer 
Table 1 Kinds of user interaction during the game of Session 2

\begin{tabular}{|c|c|c|c|}
\hline Phase & 3D world & Chat & External environment \\
\hline \multirow[t]{3}{*}{ Game: Treasure Hunt } & $\begin{array}{l}\text { Explore a labyrinth (see Fig. 6); walk, } \\
\text { run, find objects (Fig. 7), look into } \\
\text { objects (right-hand click to activate } \\
\text { pop-up window with content) }\end{array}$ & $\begin{array}{l}\text { Notify team partners about } \\
\text { your findings }\end{array}$ & $\begin{array}{l}\text { Exchange ideas with classmates } \\
\text { about where to go }\end{array}$ \\
\hline & $\begin{array}{l}\text { Select an object (right-hand click, } \\
\text { "Select" button on pop-up window) } \\
\text { Look at objects found by team } \\
\text { partners (switch view mode to "view } \\
\text { from other avatar's eyes") }\end{array}$ & $\begin{array}{l}\text { Negotiate with team partners } \\
\text { to decide if the object is } \\
\text { correct (team whisper } \\
\text { chat); each object must be } \\
\text { selected by at least two } \\
\text { team players }\end{array}$ & $\begin{array}{l}\text { Negotiate with class mates } \\
\text { about whether object is } \\
\text { correct }\end{array}$ \\
\hline & $\begin{array}{l}\text { Look at centre of labyrinth (Fig. 8) to } \\
\text { see objects found by each team (use } \\
\text { "cameras" function to see the } \\
\text { environment from anywhere in the } \\
\text { labyrinth }\end{array}$ & $\begin{array}{l}\text { Negotiate with team partners } \\
\text { to decide which objects are } \\
\text { correct (team whisper } \\
\text { chat, to keep secret from } \\
\text { opponents) }\end{array}$ & $\begin{array}{l}\text { Exchange ideas with classmates } \\
\text { about where to go and what } \\
\text { to do }\end{array}$ \\
\hline
\end{tabular}

Table 2 Kinds of user interaction during the game of Session 3

\begin{tabular}{lllc}
\hline Phase & 3D world & Chat & External environment \\
\hline Game: Olympic games & $\begin{array}{c}\text { Complete a path of slopes and } \\
\text { suspended platforms (jump, } \\
\text { steer; see Fig. 9) } \\
\text { Fly through a series of suspended } \\
\text { circles (fly, steer; see Fig. 10) }\end{array}$ & $\begin{array}{c}\text { Negotiate with team partners } \\
\text { to choose correct quiz } \\
\text { answer }\end{array}$ & $\begin{array}{c}\text { Exchange ideas with } \\
\text { classmates about correct } \\
\text { quiz answer; cheer }\end{array}$ \\
$\begin{array}{c}\text { Push a ball trough a tortuous path } \\
\text { (push, walk, run, steer) } \\
\text { Push cylinders into their holes } \\
\text { (Fig. 11) }\end{array}$ & $\begin{array}{c}\text { Select quiz answer (click on board } \\
\text { A, B, or C) }\end{array}$ & $\begin{array}{c}\text { Team partners suggest } \\
\text { answer to player }\end{array}$ & $\begin{array}{c}\text { Classmates suggest answer } \\
\text { to player, indicate where to } \\
\text { go, cheer }\end{array}$ \\
\hline
\end{tabular}

Table 3 Kinds of user interaction during common and "cultural" phases of a session

\begin{tabular}{|c|c|c|c|}
\hline Phase & 3D world & Chat & External environment \\
\hline $\begin{array}{l}\text { Welcome-first minutes } \\
\text { in a new environment }\end{array}$ & $\begin{array}{l}\text { Explore } 3 \mathrm{D} \text { environment } \\
\text { (walk, run, jump, fly, look } \\
\text { around) }\end{array}$ & $\begin{array}{l}\text { Meet foreign peers; } \\
\text { introduce oneself; } \\
\text { ask questions }\end{array}$ & $\begin{array}{l}\text { Get involved in a virtual } \\
\text { situation, with near and } \\
\text { remote participants }\end{array}$ \\
\hline $\begin{array}{l}\text { Presentation of students' } \\
\text { works/discussion of } \\
\text { educational material }\end{array}$ & $\begin{array}{l}\text { Look at content embedded } \\
\text { in 3D world (i.e., images } \\
\text { shown as texture of 3D } \\
\text { objects); activate pop-up } \\
\text { content from 3D hotspots; } \\
\text { move to the next hotspot }\end{array}$ & $\begin{array}{l}\text { Present one's class, country, } \\
\text { or homework; ask } \\
\text { questions about others' } \\
\text { works; answer guide's } \\
\text { quizzes about material }\end{array}$ & $\begin{array}{l}\text { Exchange ideas with } \\
\text { classmates about what to } \\
\text { write in the chat, how to } \\
\text { answer questions; use } \\
\text { knowledge of the material }\end{array}$ \\
\hline $\begin{array}{l}\text { Move to a new } \\
\text { environment }\end{array}$ & $\begin{array}{l}\text { Walk through a door; crash } \\
\text { against a statue; jump into } \\
\text { a hole; fly through a high } \\
\text { passage }\end{array}$ & Follow Guide's directions & Cheer \\
\hline
\end{tabular}

Other features are used for collaborative purposes, for example the view mode from another avatar's "eyes", used to check and in case double-select the objects found by team partners. However, what really promotes collaboration and involvement in the 3D world is the entire sequence of activities, which require the participation and interaction of students from different geographical locations; informal social interaction, friendly competition, the cultural discussions (about material previously studied and well-known by everybody), the pictures visible in the $3 \mathrm{D}$ environment and the HTML content that suddenly pops up on every- 


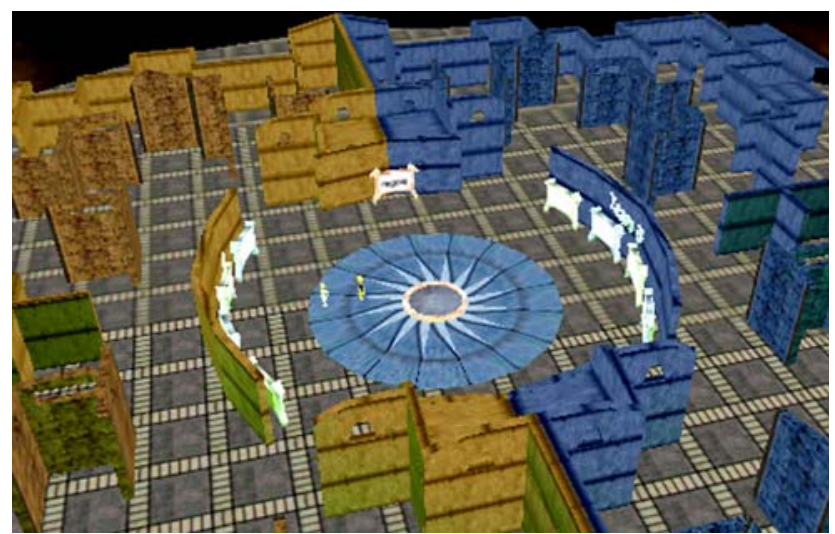

Fig. 6 Labyrinth of the Treasure Hunt

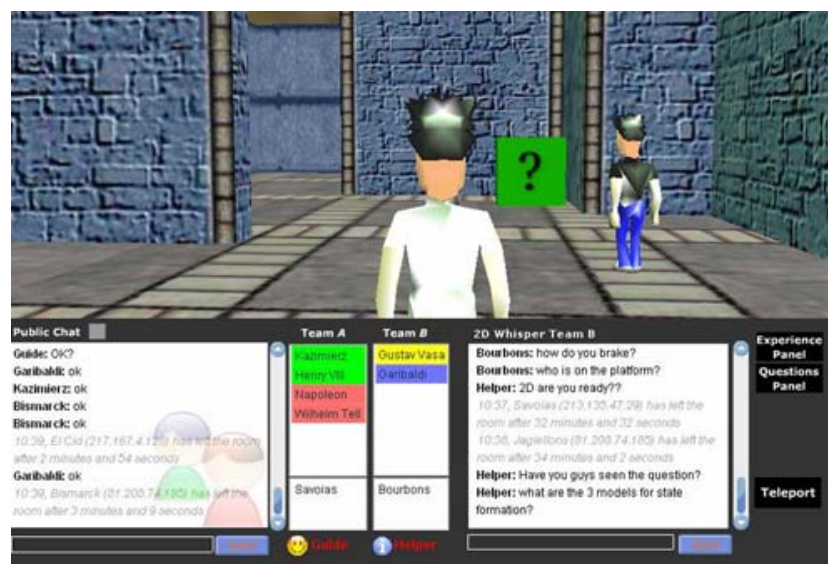

Fig. 7 Avatars found an object (both must click on it to select it)

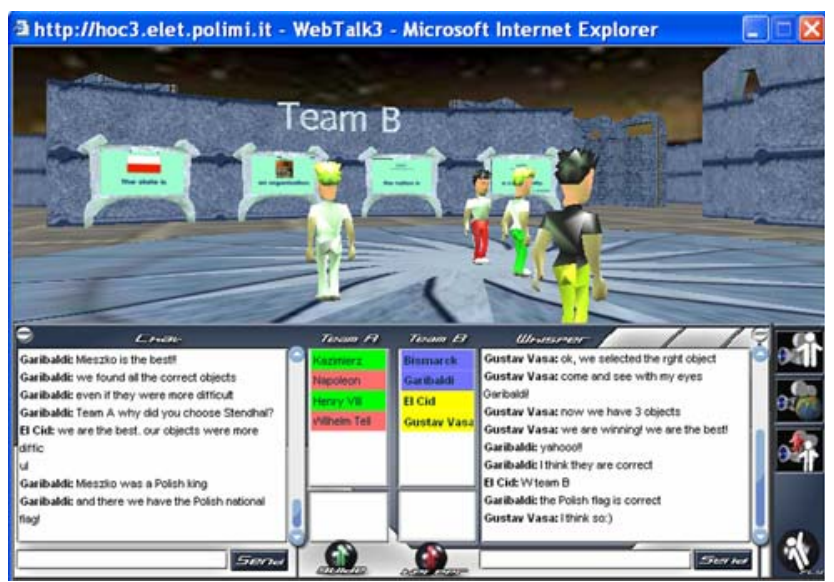

Fig. 8 Boards in the centre of the labyrinth show objects found

one's screen, the messages and directions of the online tutors-which everyone can see and is expected to follow, the playing of team games: all these elements are responsible for creating engagement, team spirit, social presence, and build the premises of a virtual

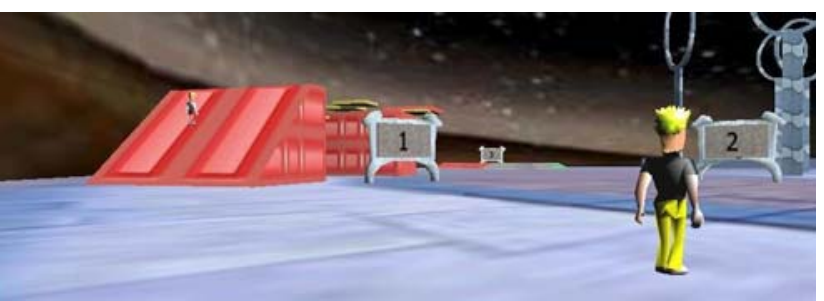

Fig. 9 Olympic game 1: jump through a path of slopes and platforms

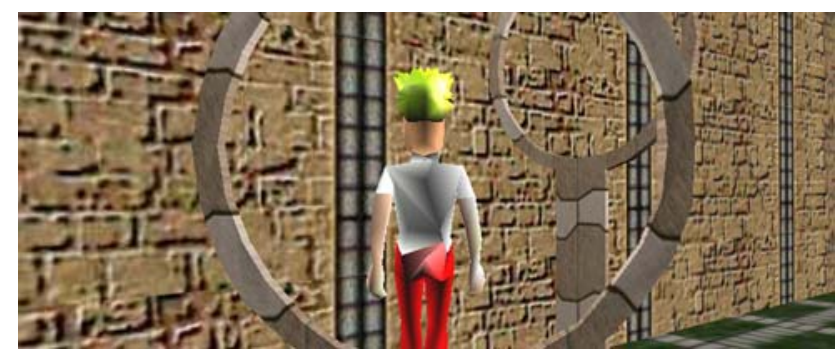

Fig. 10 Olympic game 2: fly through a set of circles

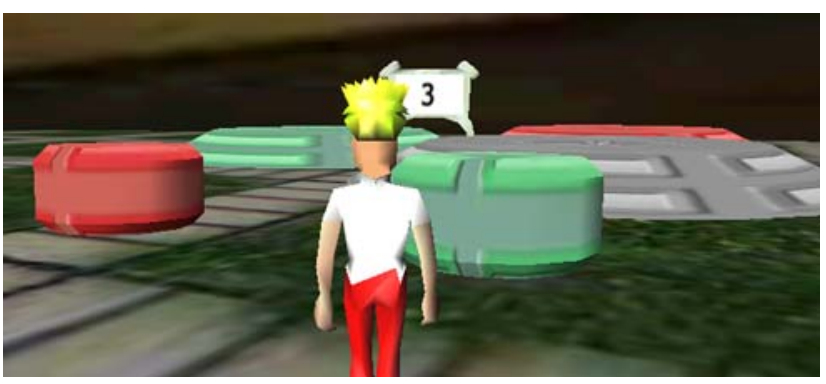

Fig. 11 Olympic game 3: push cylinders into their holes

community, much more than specific, isolated features of the virtual environment.

\section{Impact}

This section presents some of the main results in terms of educational benefits, engagement, social impact, emerging from the data collected during the implementation of L@E and S@L in Spring 2005.

\subsection{Evaluation}

Learning is a complex phenomenon. A scientific experiment (with control-group) could hardly reflect the complexity and multiplicity of the variables involved in an educational experience involving 3D and 2D web-based technology, synchronous and asynchronous interaction among students of different countries, 
in presence activities and distance education, collaborative and individual learning.

Particularly in the case of innovative technologybased educational applications, design-based research can be an effective strategy to provide findings that are important both in terms of advancing theories, and of producing socially relevant results. Large scale implementations of an innovative learning experience may leave many variables uncontrolled, collect extensive amounts of both qualitative and quantitative data from different sources, leading to problems in alignment and analysis; there may even be the need of changing methodology or design during the intervention, in order to better adapt it to the local context (Dede 2005). While this may complicate interpretation of findings, implementing well-formulated designs can have a relevant impact on the context of application, and at the same provide valuable lessons able to inform research.

Between March and May 2005, about 50 teachers and 1,000 high school students between 15 and 18 years of age took part in L@E. While skilled computer users were present in every class, the level of computer literacy varied among the population: $20 \%$ of teachers and $45 \%$ of students used computers less than $3 \mathrm{~h}$ a week. About $70 \%$ of students use computers for listening to music, playing games, and surfing the web; $50-60 \%$ also use it for schoolwork; $45-55 \%$ do not even use email or chat. The 48 participating classes belonged to 33 different high schools in 6 European countries: Italy, Poland, Spain, France, Belgium, and Norway.

S@L was implemented in the same period with almost 800 students and teachers from middle and high schools in the Italian Region of Lombardy. The same data collection methods were employed. Responserate for surveys ranged between 27 and $60 \%$ for teachers, and covered about $40 \%$ of students. At least $50 \%$ of teachers took part in the focus group after the end of the project. Both projects were repeated in the school year 2005-2006, as shown in Table 4.
This paper focuses on the results of L@E related to the school year 2004-2005, which underwent a more thorough analysis, and some results of S@L in the same period. At the time of writing, data from the 2005-2006 implementation are still under analysis; however, preliminary results tend to confirm the outcomes of the previous year. Evaluation data have been collected and triangulated from a variety of sources, in the attempt to provide a picture as complete as possible of the learning experience. Table 5 shows the methods of data collection, the qualitative and quantitative data collected from different sources in different formats, and the kinds of analysis performed on them.

All quotations from teachers' and students' comments in surveys and focus groups are reported as they are, without editing. Quotations in Italian (by S@L participants) have been translated into English.

\subsection{Educational impact}

\subsubsection{Knowledge}

Thanks to the online virtual world students from different countries can meet, communicate in real time, discuss, share perspectives, and also play. Interaction with foreign students stirs the students' interest and curiosity for the cultural themes, and data suggest it is a major factor in their motivation to learn, as shown in the following comments by students in L@E surveys:

"I liked the different approach to history very much, in fact I was more interested in studying it and I could understand different aspects of European's feelings."

"It was a very nice experience because I learn many of the history of other countries".

"I found more interesting study the history of European's states"

Table 4 Participants in Learning@Europe and Stori@Lombardia between 2004 and 2006

\begin{tabular}{lllllll}
\hline & \multicolumn{2}{l}{ Stori@Lombardia } & & & Learning@Europe \\
\cline { 2 - 3 } & Mar-May 2005 & Nov 2005-Apr 2006 & & Mar-May 2006 & Nov 2005-Jun 2006 \\
\hline Students & Approximately 720 & Approximately 480 & & Approximately 1,000 & Approximately 3,400 \\
Teachers & 39 & 24 & & 50 & 181 \\
Schools & 24 & 18 & & 33 & 94 \\
Geographic areas & 10 towns in Lombardy & 12 towns in Lombardy & & 6 European countries & 16 European countries \\
Sessions & 36 & 24 & & 48 & Approximately 4,630 \\
Total participants & Approximately 1,260 & & & 160 \\
\hline
\end{tabular}


Table 5 Data collection and analysis of Learning@Europe and Stori@Lombardia 2004-2005

\begin{tabular}{|c|c|c|c|}
\hline Source & Collection methods & Data collected & Analysis methods \\
\hline \multirow[t]{2}{*}{ Teachers } & $\begin{array}{l}5 \text { online surveys (about demographic } \\
\text { data and expectations before } \\
\text { starting, organization of class work } \\
\text { before and during each session, } \\
\text { evaluation of L@E features, } \\
\text { educational impact) }\end{array}$ & $\begin{array}{l}\text { L@E: responses from } 50 \text { to } 98 \% \text { of } \\
\text { teachers }(50 \% \text { respondents to the } \\
\text { survey about global educational impact } \\
\text { after Session } 4) \\
\text { S@L: responses from } 27-60 \% \text { of teachers }\end{array}$ & $\begin{array}{l}\text { Quantitative analysis of close-ended } \\
\text { questions; L@E: cross-analysis; } \\
\text { graph visualization; qualitative } \\
\text { analysis of open-ended questions: } \\
\text { coding by themes, classification }\end{array}$ \\
\hline & $\begin{array}{l}\text { Focus group or in-depth interview } \\
\text { after the end of the project (video- } \\
\text { taped, detailed notes taken) }\end{array}$ & $\begin{array}{l}\text { L@E: } 12 \text { teachers from } 5 \text { countries } \\
\text { met in Milan in June, to assess } \\
\text { survey results and provide insights } \\
\text { S@L: focus group with about } 15 \text { teachers }\end{array}$ & $\begin{array}{l}\text { Reading of focus group transcripts; } \\
\text { identification of relevant concepts } \\
\text { and examples to explain data }\end{array}$ \\
\hline \multirow[t]{2}{*}{ Students } & $\begin{array}{l}2 \text { online surveys (about demographic } \\
\text { data and expectations before } \\
\text { starting, impressions, preferences, } \\
\text { and learning impact after the end) }\end{array}$ & $\begin{array}{l}\text { L@E: responses from } 40 \text { to } 60 \% \text { of } \\
\text { students ( } 400-600 \text { respondents) } \\
\text { S@L: responses from } 40 \% \text { of students }\end{array}$ & $\begin{array}{l}\text { Quantitative analysis of close-ended } \\
\text { questions }\end{array}$ \\
\hline & Student-produced artefacts & $\begin{array}{l}\text { L@E: about } 48 \text { works (in Word and } \\
\text { HTML) created by students about } \\
\text { history and its local material evidences } \\
\text { S@L: about } 36 \text { students-produced works }\end{array}$ & $\begin{array}{l}\text { Informal evaluation of works' global } \\
\text { quality; choice of sample works for } \\
\text { examples }\end{array}$ \\
\hline Observers & $\begin{array}{l}\text { Video-taping of class interaction in } \\
\text { schools }\end{array}$ & $\begin{array}{l}\mathrm{L} @ \mathrm{E} ; \text { about } 7 \mathrm{~h} \text { of class interaction } \\
\text { videotaped }\end{array}$ & $\begin{array}{l}\text { Identification of excerpts showing } \\
\text { involvement }\end{array}$ \\
\hline \multirow[t]{2}{*}{ Tutors } & $\begin{array}{l}\text { Online report and Word debriefing } \\
\text { after every session (evaluating } \\
\text { involvement, cultural, } \\
\text { technological and organizational } \\
\text { issues) }\end{array}$ & $\begin{array}{l}\text { L@E: reports for each of the } 48 \text { sessions } \\
\text { S@L: reports for each of the } 36 \text { sessions }\end{array}$ & $\begin{array}{l}\text { Quantitative analysis on answers to } \\
\text { closed-ended questions in online } \\
\text { report; Word version used for } \\
\text { reference }\end{array}$ \\
\hline & Forum reports & $\begin{array}{l}\text { L@E: reports of forum situation every } \\
10-15 \text { days }\end{array}$ & Reports used for reference \\
\hline \multirow[t]{3}{*}{ System } & Recording of chat logs & $\begin{array}{l}\text { L@E: transcripts of all } 48 \text { chat discussions } \\
\text { S@L: transcripts of all } 36 \text { chat discussions }\end{array}$ & $\begin{array}{l}\text { L@E: qualitative analysis on all chat } \\
\text { logs: all messages coded for } \\
\text { evidence of: engagement, cultural } \\
\text { skill, discipline, problems, etc.; } \\
\text { graph visualization }\end{array}$ \\
\hline & Recording of forum posts & $\begin{array}{l}\text { L@E: about } 2000 \text { posts in } 41 \text { forums, plus } \\
\text { usage data (username, date and time of } \\
\text { posting) } \\
\text { S@L: over } 3000 \text { posts in } 29 \text { forums }\end{array}$ & $\begin{array}{l}\text { L@E: quantitative analysis on system } \\
\text { usage data; qualitative analysis of } \\
1 \text { forum ( } 341 \text { messages). Coding of } \\
\text { each post basing on behaviours } \\
\text { expressed) }\end{array}$ \\
\hline & $\begin{array}{l}\text { Recording of sessions from the } \\
\text { tutor's screen }\end{array}$ & L@E: about $12 \mathrm{~h}$ of sessions recorded & \\
\hline Experts & Expert review of results & $\begin{array}{l}\text { L@E: independent review on survey } \\
\text { results by Dr. Thomas C. Reeves } \\
\text { and Dr. Michael Orey, University } \\
\text { of Georgia, Athens; independent review } \\
\text { on forums by Jennifer Preece, } \\
\text { University of Maryland, College Park }\end{array}$ & \\
\hline
\end{tabular}

A middle school student participating in S@L wrote proudly on the forum that now she was able to tell the story of many of the monuments she saw around her town, unknown even to her parents.

The Guides' reports show that in $60-80 \%$ of L@E sessions and in $97 \%$ of S@L sessions most students were able and ready to answer factual questions correctly, showing their knowledge of the contents.

Teachers certainly seem to find the project effective as far as knowledge of history is concerned. In L@E surveys, about two thirds of them rate their students' improvements in understanding historical issues either good or very good, and less than $10 \%$ express a negative judgement. Between 43 and 62\% of teachers in S@L also rate their students' improvements in history either good or very good, and negative ratings do not exceed $15 \%$.

One of the greatest knowledge-related benefits was learning about the history of other countries, in comparison with their own. L@E teachers comment in the surveys: 
"I think that the project enables to reduce differences in the history curricula among European countries. Polish students learn during their lessons more about the history of countries such as Italy, France or Spain then their West-European colleagues about the history of Poland."

"the students became more aware of their history also because they had to think about the most important points to focus for other students of other countries"

"Students from participating countries could get to know different points of view on some aspects of European and national history."

\subsubsection{Skills}

Group work improvements are illustrated in the Social Impact section.

In L@E, no teacher rated the students' improvements in the use of English as a foreign language below average. About $32 \%$ of the teachers found the improvements good and $43 \%$ very good.

In their comments teachers refer not only to the synchronous conversations via chat, but also to the study materials, the forums and the preparation of the assignments - all of which involved a fair amount of English practice. Multiple positive effects were observed:

"Lots of new vocabulary.", "they were better than I expected"

"With mistakes, but independent"

"For my students the first opportunity to use

English in authentic situation and with authentic materials."

About $46 \%$ of the students perceived their improvements as good and $23 \%$ as very good. From their comments in the survey it is clear that synchronous interaction with their foreign friends in the chat-and asynchronous communication in the forum-were the key factors that stimulated them to practice and improve their functional English skills. Below are some of their comments:

"It was a new way on learning english, in fact we weren't so attached to the grammar use of the word. We were more concentrated in use the lenguage to have a better comprehensio of the dialogue!"

"it's a real active way to learn english. it's not like in class. you can talk of whatever you want."

"I'd never thought to talk to other people in english in a so good manner".
A student wrote in a forum:

"When you learn a language, you should remember that constant repeating is necessary. Unless you do it, you wont learn anything. The language must be constanly in use. That's one of the reasons why I enjoy this forum so much [;)] It forces us to use English so we learn it far better :)"

Also some teachers' comments after the various sessions show the powerful effect of online interaction on the students' motivation and attitude towards the use of English:

"For the first time I saw my students reading and above all writing English on their own initiative!" "they were so enthusiastic and excited that it was difficult for us to calm down everybody, it is so different from a regular lesson that I'm not sure they have realised they have communicate in English; you know French students are so reticent to speak English and in this situation, you could feel that everything was going on well."

Also in the use of technologies for learning, no teacher rated students' improvements below average. About $47 \%$ rated them good, $42 \%$ very good, and the rest is average. In S@L 43\% of teachers reported good improvements, $33 \%$ very good, $19 \%$ average and $5 \%$ poor.

About 62\% of L@E students rate their improvements in technological skills good or very good: "this project also allowed us to use and discover new communication technologies, which is useful according to us in our future pupil's life." Benefits extended also to the teachers! A teacher told us:

"Due to the project I had the opportunity to use information technology in my teaching process. I learned more about it and I think I well be using it more in the future."

\subsubsection{Attitudes}

Improvements in the students' attitudes (concerning engagement in school activities, interest for history and for people of other areas, overall motivation) were rated good or very good by about $80 \%$ of L@E teachers, and by about $75 \%$ of S@L teachers.

The following quotes from L@E teachers' surveys and focus group illustrate the project's effects on the students' attitudes.

Motivation: 
"Students were enthusiastic, they gave very good feedback"

"The students worked together as a group, they were involved and interested, kept asking about the project and really wanted to be involved in it"

Interest in history:

"They were enthusiastic and they were also very interested in history, a subject that they do not study with much pleasure"

"my students had the lowest grades in history in the whole school. It was perfect for them because they realized that history can be fun and cultural interaction is also a kind of history. They realized that history can be interesting. My students definitely benefited from it, even if they were not the best."

A middle school student even wrote on the forum that he would like to be an historian when he grows up. Interest for Europe and European identity:

"Now they are interested in what's happening. They asked about what's been happening with the European Constitution and the Referendum... In March, before the project, they did not care."

"Before L@E, my students just felt French. Now they feel French and European."

Attitude towards foreign peers (students' quotes from forums and focus group):

"In these days we have known each other better and we have found out many things in common! We love sports and music even if Italian music and sports are different from the Belgian ones. Anyway we are becoming a united team and interact a lot thanks to the forum and the use of English!" "... but the most interesting thing was the surprise, the discovery during the dialogue with fellow students of other nations, that we are not so different after all. We did the same things! When we were losing and tried to make light of it, when we complained, or when something funny happened... we told the same jokes and laughed at the same things".

\subsection{Engagement}

Online tutors report that many (if not all) of the students seemed to be "engaged, motivated, excited", in 90.7\% of L@E sessions, and in 94.1\% of S@L sessions.

In the qualitative analysis of L@E chat transcripts, the students' engagement has been quantified as the number of students' contributions in the chat denoting interest and participation-particularly questions, such as "Garibaldi, where do you come from?"-and expressing some content. The average number of messages per session expressing engagement approaches 90 (Fig. 12), where usually chat transcripts count approximately 400-500 lines of students' messages. Another measure of the students' involvement is enthusiasm. The students' enthusiasm has been quantified as the number of students' contributions in the chat denoting appreciation and excitement, such as: “wow a labirinth!!!!”, “We love you!!!!!!!!!!”, etc. The average number per session of messages expressing enthusiasm is 17 , with peaks reaching 43 .

When teachers describe in the surveys their students' level of participation during L@E online sessions, $49.32 \%$ of them use the word "enthusiastic". They comment in the surveys:

"Students are the main actors and enjoy themselves because the game is so interesting."

"They were completely involved in the game."

A teacher of S@L reports that "The kids were enthusiastic and at some points they reached 'stadium' levels of engagement".

As for the students' own impressions after the end of the projects, $49 \%$ of survey respondents $(N=376)$ rate L@E good, 18\% very good, and only 5\% below average. They comment: "It has been an interesting and amusing experience and I hope that the relations with some students of other country to continue.", "IT HAS BEEN THE FIRST TIME I ENJOYED MYSELF AT SCHOOL!!", and offer suggestions such as: "involving more students of more countries", "Why not a project about geography?", etc.

Of the 320 student-respondents to S@L final survey, only $6 \%$ rate the project below average: $47 \%$ find it good and $29 \%$ very good. They write: "I liked to interact with students of other schools and study history in the form of a game", and "sessions should have been at least 10!".

\subsection{Social impact}

\subsubsection{Relationships with remote peers}

Online tutors reported that in $89.8 \%$ of L@E sessions many or all of the students seemed eager to chat with peers and get to know them better. In S@L this happened in $93.9 \%$ of sessions.

Much of the engagement and enthusiasm are actually due to the excitement of meeting new friends from faraway countries and interacting with them: $38.46 \%$ of the students who in the final survey indicated Session 1 as their favourite session gave reasons such as: "Be- 
Fig. 12 Every square represents one session in the 3D world. The colour represents the kind of session (Session 1 is red, Session 2 blue, etc.). The squares representing the four sessions in a particular L@E experience are connected through arrows. Their $y$-value represents the number of students' contributions in the chat expressing engagement

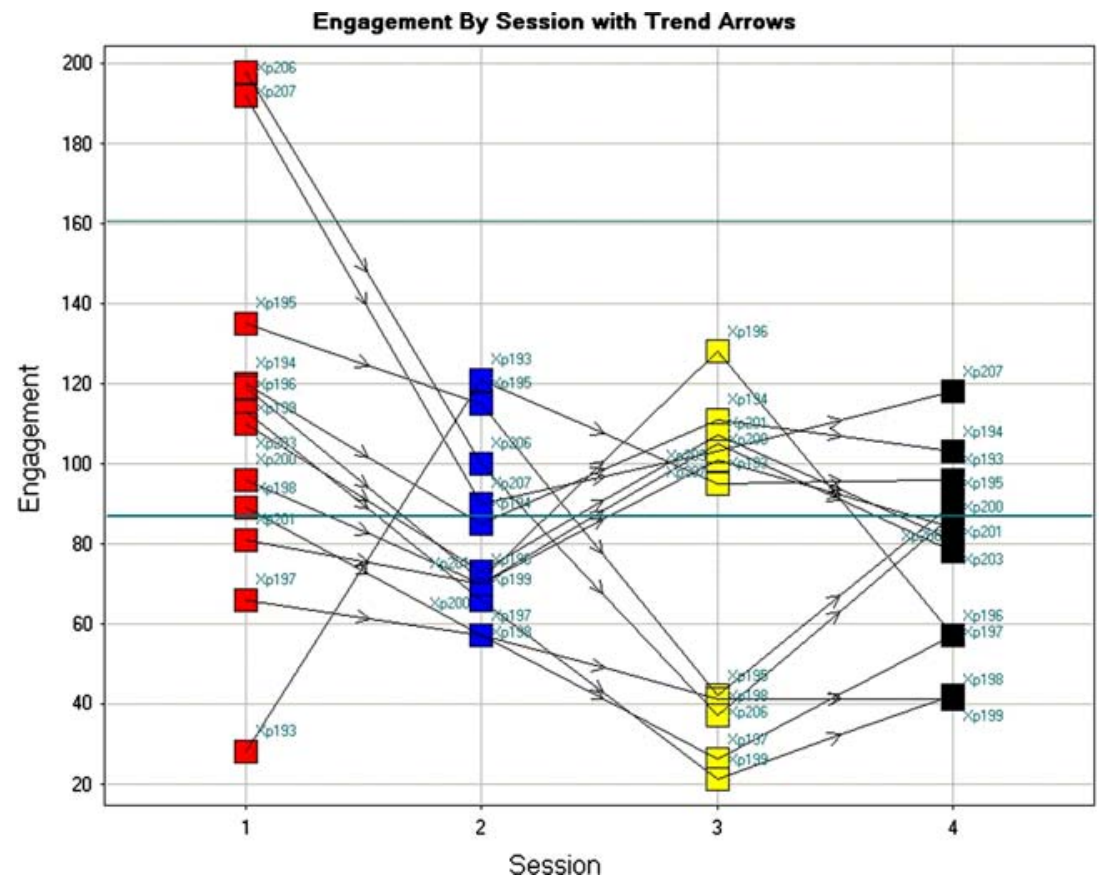

cause we met other students from different European countries", or "Because it was the first time that we talked in class with foreign students and we had a great time". Moreover, "meeting foreign students" resulted from students' ratings the second most attractive aspect in the whole project, surpassed only by "doing something different at school".

The following excerpts from students' answers to survey open-ended questions show how L@E students found the interaction with peers of other countries not only enjoyable, but also interesting and stimulating:

"Above all I liked meeting foreign students because now I know more things about cultures different from mine"

Forum qualitative analysis shows how some of the ties created during online sessions and strengthened on the forums continued also after the end of the project. One forum contains at least ten messages of students exchanging contact information and proposing to meet in the real world:

"Now all is over... what about to organize a trip... so we can meet each other! We come there and you come here! The school can help to organize!'.

\subsubsection{Relationships with teachers}

Students seemed to appreciate it when teachers participated to discussions in the forums, and developed a much more informal relationship with the teachers. The following is the message of a Polish girl to her teacher.

"Thank you, our dear teacher, mrs. ****;] What a pity you used by beloved emoticon inly once [;)] I hope it would spread through whole message ;D

But never mind. I simply wanted to thank you officially for your sacrifice you had done for us during both previous sessions and generally you do all the time [;)]. You always do concern of us and you are a very helpful person at all, indeed :) I'm very grateful of all you are doing for us and particularly me :) Thank you [;)]"

\subsubsection{Relationships with classmates}

Besides improving relationships with teachers and creating new ones with foreign friends, students learned a great deal about how to work together with their classmates and turn their class into a team. Almost all L@E teachers' ratings of students' improvements in working in group were above average: $60 \%$ good, and $35 \%$ very good. Only 5\% rated them average (Fig. 13). Almost $70 \%$ of the students also rate their own improvements in group work above average.

Teachers helped students organizing groups, roles and tasks. Division of labour and turn rotation seemed 




Fig. 13 L@E teachers' evaluation of students' improvements in working in groups

to work fairly well in many classes. L@E teachers comment in the surveys:

"I encouraged the students to cooperate with one another and learn how to work in groups. They turned out to be excellent, bright students who are willing to face new challenges."

"Students were able to cooperate to achieve the common goals. It forced the integration of the class."

"Division of the class into sub-teams to make the work more effective has united the students."

Several S@L teachers cite group work in the surveys as the best aspects of the project:

"Group work, the 'push' of the competition, taking advantage of different skills to obtain a result, collaboration"

Students also showed to enjoy group work: S@L participants rated improvements in this skill the highest of all (an average of four on a five-points scale).

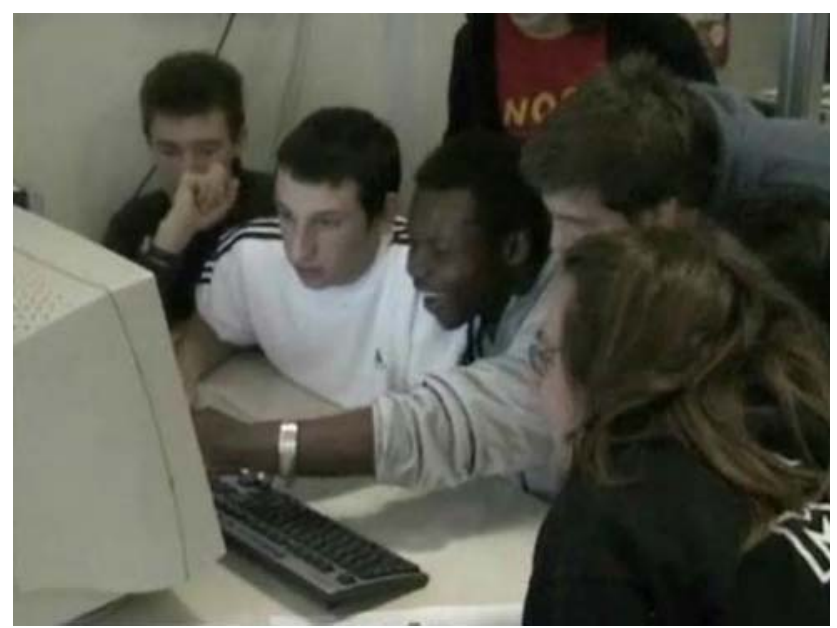

Fig. 14 Students gathered around a PC during a L@E online session

\section{Conclusions}

L@E is a complex educational service in which VR plays a central role; it provides substantial educational benefits and supports the creation of lively communities, mainly thanks to the sense of social presence in which participants are involved.

First of all, it reinforces the community in the class: students feel united as if they were "a soccer team". They are usually divided into sub-groups, with specific tasks (those who control the avatars, those who have the interviews at hand for answering the questions, those in charge of the English dictionary, who help with translations, and so on, according to the teachers' and students' creativity). In spite of the fact that only three students at a time have their hands on the keyboard (two maneuvering the avatars and one discussing in the 2D chat), the others gather around the computers, suggesting answers and cheering. In this case we can talk of an "extended" virtual presence, as videos clearly show (Fig. 14), a phenomenon still unknown in literature.

Second, Learning@Europe creates a virtual community of the students-from four different European countries-who take part together in the same experience: they have to remotely perform a number of cooperative tasks, the most difficult of which is the preparation of a research over a common topic. Survey data and forum entries demonstrate that they become a team and they feel that their success depends on everybody's work.

Third, it creates a long-lasting community of those who have taken part in the program (both teachers and students) that crosses the borders of the single experiences. Students and teachers keep in touch in the common forum (that gathers all who have taken part in the project), discussing issues such as the different European school curricula or their different life-styles.

The novelty of the L@E's approach in this respect is the mixture of synchronous (in the 3D world and in the 2D chat) and asynchronous interaction (via forums) among participants connected from different locations, and their very location becomes an extremely meaningful resource, in that it allows them to contribute unique knowledge and perspectives to history discussions. Synchronous interaction provides the engagement and enhances curiosity; asynchronous interaction allows a deeper acquaintance among the community's members, who cooperate in performing tasks and exchange opinions, not only as a group, but also individually. The effect is so powerful that people do not want to "quit the community" once the experience is over and they keep interacting in the forum or remain 
in touch by means of e-mail. In a few cases, teachers have even arranged meetings in the real world.

What is more, interacting and discovering about others is often an occasion to redefine one's own identity (Wenger 1998). When introducing themselves to the world, students need to identify the aspects that really characterize them as "Polish" in Europe, for example, or that distinguish them as the "inhabitants of Crema" among all the other towns in Lombardy. In an increasingly interconnected society, the need for being able to live together knowing each other and overcoming conflicts is enormous. Virtual reality, along with Internet technologies, offers a way to put people in contact and enable them to know each other, work together, create ties. If well designed, an experience in a virtual world can make a virtual community just feel "real".

In our opinion, the crucial element for the creation of the above communities is the sense of social presence that VR powerfully supports: participants feel involved in a common situation, they feel united as a group, all devoted to the same goal. In this respect, the cultural competition plays a fundamental role. One may object that the service is so engaging just in that it resembles a videogame, or simply because it is so different from normal school activities. For sure the unusual, playful aspect is appreciated by students: survey data confirm this. However, apart from some of the activities, the experience as a whole could hardly be described as a game. The workload for the students is quite huge, and the background materials (interviews to experts at academic level) are complex and challenging, as the teachers themselves report. In the design of the experience, the playful aspect is meant as a lever for motivating the students to study and perform difficult assignments.

\section{Future steps}

Our future steps are:

- Enlarging the number of participating schools, involving more European countries. About 160 classes from 16 European countries took part in L@E in year 2005-2006, for a total of approximately 3,400 students. For school year 2006-2007 we plan to involve 300 classes from at least 20 European countries (contacts with educational authorities are currently under way).

- Applying the format to new content. L@E is based on an educational format, that has already been applied to other kinds of content: SEE (Shrine Educational Experience), deployed in cooperation with the Israel Museum between 2002 and 2004, was about the Dead Sea Scrolls; S@L is about medieval history in Italy. We are currently designing a similar service on the topic of how sport can help socially impaired young people, in cooperation with the Italian fashion house Benetton. It will start from September 2007.

- Further investigating the pedagogical impact, refining the evaluation methods. International partnerships are already active, with Dr. Jenny Preece (University of Maryland), Dr. Thomas Reeves and Dr. Michael Orey (University of Georgia, Athens); we heartily welcome any scholar who may want to join us in the research!

Acknowledgments The authors wish to acknowledge the work of all the people who contributed to the success of the programs described above. They are too many to list them all: their names can be found in the websites http://www.learningateurope.net and http://www.storialombardia.it. We also thank Accenture International Foundation and the regional Government of Lombardy for their support to L@E and S@L, respectively.

\section{References}

Barbieri T (2000) Networked virtual environments for the web: the WebTalk-I and WebTalk-II architectures. IEEE for Computer Multimedia and Expo 2000 (ICME), New York

Barbieri T, Paolini P (2000) Cooperative visits to WWW museum sites a year later: evaluating the effect. In: Bearman D, Trant J (eds) Museums and the Web: selected papers from an international conference. Archives and Museum Informatics, Pittsburgh, 173-178

Barbieri T, Paolini P (2001) Cooperation metaphors for virtual museums. In: Bearman D, Trant J (eds) Museums and the Web, selected papers an international conference. Archives and Museum Informatics, Pittsburgh, 115-126

Barbieri T, Paolini P, Alonzo F, Gaia G, Loiudice P (1999) Visiting a museum together: how to share a visit to a virtual world. Museums and the Web, New Orleans

Barbieri T, Garzotto F, Beltrame G, Gritti M, Misani D (2001) From dust to StarDust: a collaborative virtual computer science museum. In: ICHIM 2001 international cultural heritage informatics meeting, Milano

Biocca F (1997) The cyborg's dilemma: embodiment in virtual environments. In: Proceedings of the second international conference on cognitive technology, humanizing the information age, pp 12-26

Brogni A, Slater M, Steed A (2003) Physiological responses to breaks in presence: a pilot study. In: Proceedings of presence 2003: the 6th annual international workshop on presence

Bucciero A, Mainetti L, Paolini P (2005) Flexible 3D collaborative virtual environment: WebTalk04. In: Proceedings of VSMM-virtual systems and multimedia. Ghent, 3-7 October 2005

Carassa A, Morganti F, Tirassa M (2004) Movement, action and situation in: presence. In: Proceedings of the seventh annual international workshop, technical University of Valencia, Spain, 13-15 October 2004 
Dede C (2005) Why design-based research is both important and difficult. Educ Technol 45(1):5-8

Di Blas N, Hazan S, Paolini P (2003a) The SEE experience. Edutainment in 3D virtual worlds. In: Bearman D, Trant J (eds) Museums and the Web, selected papers from an international conference. Toronto, Archives and Museum Informatics, pp 173-182

Di Blas N, Paolini P, Poggi C (2003b) SEE (Shrine Educational Experience): an online cooperative 3D environment supporting innovative educational activities. In: Proceedings of ED-MEDIA. World conference on educational multimedia. Hypermedia and Telecommunications, Honolulu

Di Blas N, Paolini P, Poggi C (2004) Learning by playing. An edutainment 3D environment for schools. In: Proceedings of ED-MEDIA. World conference on educational multimedia. Hypermedia and Telecommunications, Lugano, 21-26 June 2004

Di Blas N, Gobbo E, Paolini P (2005a) 3D worlds and cultural heritage: realism vs. virtual presence. In: Trant J, Bearman D (eds) Museums and the Web In: Proceedings. Toronto, Archives and Museum Informatics

Di Blas N, Gobbo E, Paolini P, Poggi C (2005b) 3D worlds for education: cooperation and virtual presence. In: VSMM conference (virtual reality at work in the 21st century), Ghent, 3-7 October 2005

Di Blas N, Paolini P, Poggi C (2005c) A virtual museum where students can learn. In: Tan L, Subramaniam R (eds) Elearning and virtual science centers. Idea Group, Hershey

Di Blas, N., Paolini, P, Poggi C (2005d) 3D worlds for edutainment: educational, relational and organizational principles. In: PerCom Workshops Proceedings IEEE international workshop on pervasive eLearning IEEE Press, New York, pp 291-295

Di Blas N, Paolini P, Poggi C (2005e) Educational benefits: testing and evaluation of a collaborative $3 \mathrm{D}$ world. In: Proceedings of ED-MEDIA-world conference on educational multimedia. Hypermedia and Telecommunications. AACE, Montreal

Di Blas N, Poggi C, Reeves T (2006) 3D for education: design and evaluation of educational benefits. In: International conference of the learning sciences. Accepted paper

Hall ET (1966) The hidden dimension. Doubleday, Garden City

Heeter C (1992) Being there: the subjective experience of presence. Presence Teleoperators Virtual Environ 1(2):262-271

Held RM, Durlach NI (1992) Telepresence. Presence Teleoperators Virtual Environ 1(1):109-112
Johnson B (2005a) Place-based storytelling tools: a new look at Monticello. In: Bearman D, Trant J (eds) Museums and the Web. Selected papers from an international conference. Toronto: Archives and Museums Informatics

Johnson S (2005b) Everything bad is good for you. How today's popular culture is actually making us smarter. Riverhead Books, New York

Kenderdine S (2001) 1000 Years of the Olympic games: treasures of ancient Greece. Digital reconstruction at the home of the gods. In: Museums and the Web, selected papers an international conference. Archives and Museum Informatics, Pittsburgh

Lombard M, Ditton T (1997) At the heart of it all: the concept of presence. J Comp Mediat Commun 3(2) (On-line)

Mikropoulos TA, Strouboulis V (2004) Factors that influence presence in educational virtual environments. Cyberpsychology Behav 7(5):582-591

Postmes T, Spears R, Lea M (2002) Intergroup differentiation in computer-mediated communication: effects of depersonalization. Group Dyn 6:3-16

Preece J (2000) Online communities: designing usability, supporting sociability. Wiley, Chichester

Schubert TW, Friedmann F, Regenbrecht HT (1999) Decomposing the sense of presence: factor analytic insights. In: Presented at the second international workshop on presence, University of Essex, UK, April 6-7 1999. Retrieved November 11, 2005 from http://www.uni jena.de/ sth/vr/ insights.html

Sheridan TB (1992) Musings on telepresence and virtual presence. Presence Teleoperators Virtual Environ 1(1):120-126

Slater M (1999) Measuring presence: a response to the Witmer and Singer presence questionnaire. Presence Teleoperators Virtual Environ 8(5):560-565

Slater M, Steed AJ (2000) A virtual presence counter. Presence Teleoperators Virtual Environ 9(5):413-434

Sproull L, Kiesler S (1986) Reducing social context cues: electronic mail in organizational communication. Manage Sci 32(11):1492-1512

Walther JB (1992) Interpersonal effects in computer-mediated interaction: A relational perspective. Commun Res 19(1):52-90

Wenger E (1998) Communities of practice. learning, meaning, and identity. Cambridge University Press, Cambridge

Witmer BG, Singer MJ (1998) Measuring presence in virtual environments: a presence questionnaire. Presence Teleoperators Virtual Environ 7(3):225-240 